\title{
Research on the Physico-Chemical Characteristics of Soils Locality Giuvarasti, Olt County in Correlated with the Limiting Factors of Agricultural Production
}

\author{
Anca-Luiza Stănilă (Corresponding author) \\ Department research in soil science, agrochemical and environmental protection \\ Laboratory of soil sciences and sustainable development \\ National Research Institute for Soil Science \\ Agrochemistry and Environment Protection - ICPA \\ 61 Mărăşti Blvd, District 1, 011464, Bucharest, Romania \\ E-mail: luizastanila2011@yahoo.com
}

Received: March 8, 2020 Accepted: April 28, 2020 Published: April 30, 2020

Doi: 10.5296/jab.v8i1.16936 URL: https://doi.org/10.5296/jab.v8i1.16936

\begin{abstract}
The purpose of this paper is the pedological characterization of land in order to update General Urban Plan the locality Giuvarasti, Olt County.

Highlighting the soil locality Giuvarasti calls for a better understanding of their, the variability of their correlation with the main natural factors.

Thus, there has been a general characterization of the soil cover corresponding to surface designated to be introduced in buildable urban, the presentation of the soils, the main physical and chemical characteristics. Each area it was characterized in terms of soil (soils, the area occupied by each soil in part) and of agronomic (site evaluation, framing in the class quality and the main limitation on the use of agricultural).
\end{abstract}

Keywords: Site evaluation, Giuvarasti, Physico-chemical characteristics, Buildable urban, Limiting factors of agricultural production

\section{Introduction}

General Urban Plan is the main instrument for strategic planning and operational, thus guiding nature, strategic and specific regulations. This is the main tool for operational planning, the legal basis for implementing programs and actions for development in a locality. 


\section{Macrothink}

Each administrative territorial unit it is bound their make and to approve the General Urban Plan, to be updated regularly to 5-10 years.

The total surface of locality Giuvarasti is 3222.85 ha, of which 254.55 ha are present built. Surface proposed to be introduced in buildable urban represents 68.37 ha, and their distribution in the territory commune and associated soil units are shown in the soil map. Framing in the class quality of land it was made by the method site evaluation, in natural conditions.

In terms of geographical location, administrative territory of locality Giuvarasti it is located in the south-eastern of Olt county, on the right of the River Olt, border with Teleorman county.

Site evaluation operation is complex knowledge of growing conditions and fruit-bearing plant, and determining the degree of suitability of these conditions, for each part of culture and use.

For agricultural land site evaluation aims at establishing notes and the classes of suitability for different crops and the class quality of land for agricultural use: land in crop, pasture, hay-field, orchards and vine.

\section{Materials and Methods}

Pedological characterization of the soil cover was based on data from research made on the field.

Soil classification level type, subtype were made in accordance with Romanian System of Soil Taxonomy (SRTS, 2012), ICPA, Bucharest.

Site evaluation as natural made using synthetic biophysical parameters, converted into ecological indicators characterization of soils or ecopedological indicators.

Ecopedological indicators used for site evaluation marks are specified in the work "Methodology development of soil studies" (3 Volume), ICPA, Bucharest, 1987:

- the annual average temperature - corrected values (correction it is based on slope and land aspect)

- average annual rainfall - corrected values (correction it is based on slope and permeability)

- gleization

- stagnogleyzation

- $\quad$ salinization and alkalization

- texture in the surface horizon

- $\quad$ soil pollution

- slope

- $\quad$ the presence of landslides

- groundwater depth

- floodability

- total porosity

- total $\mathrm{CaCO}_{3}$ content on depth up to $50 \mathrm{~cm}$

- reaction $(\mathrm{pH})$ in the surface horizon 


\section{Macrothink}

- degree of base saturation in the surface horizon

- $\quad$ edaphic volume

- reserve of humus depth of 0-50 cm

- waterlogging of surface

Each crop and use, according to factors listed, receives coefficients ranging from $0-1$, as acquisition that is totally bad or optimal for use or slope considered. Note of evaluation to natural conditions is obtained by multiplying 100 product coefficients indicators listed above and is established for the territory mapped the units ecologically homogeneous territory category of use the time when mapping (Teaci, 1980).

For the category of use land in crop, note of evaluation natural represents the arithmetic mean of notes of evaluation for 8 cultures the area spreading most, namely: wheat, barley, corn, sunflower, sugar beet, potato, soy and peas/beans, and for orchards it is arithmetic mean of notes of evaluation for species apple, pear, plum which add as the case, note species cherry or peach or apricot.

For vine, note of evaluation natural it is arithmetic mean the two categories. For uses (land in crop, pasture, hay-field, orchards and vine) class quality setting from I to $\mathrm{V}$ as follows:

$\begin{array}{ll}\text { Class quality } & \text { Interval } \\ \text { Class I } & 81-100 \\ \text { Class II } & 61-80 \\ \text { Class III } & 41-60 \\ \text { Class IV } & 21-40 \\ \text { Class V } & 1-20\end{array}$

Map making materials were used following map: Romanian soil map, scale 1:200.000, sheet Turnu Magurele. Thus, those maps were scanned, then the images were vectorized. He data were then processed using ArcView the projection system Stereo 70. For each map, the computer result in a "polygon layer" mapping each polygon representing a territorial unit. Cartographic data validation was done by overlapping polygons layer the source data. Each territorial mapping unit, were entered as attributes: soil genetic unit, the surface texture, the parent material, pedogenetic processes and the relief.

\section{Results and Discussions}

Giuvarasti commune is located in Olt county, in the Romanati Plain, subdivision of the Romanian Plain, on the right of the River Olt, border with Teleorman county (Stănilă et al., 2010).

From geomorphological locality Giuvaraşti is situated on terraces of the Danube (occupying the western part of the territory studied), and a relatively small portion of the Olt floodplain (occupying the eastern part of the territory studied) (Figure 1).

Olt floodplain it is present both the right, and the left River Olt and is a vast alluvial plain with a altitude of $30 \mathrm{~m}$ having a microrelief consisting from bed and abandoned meander (Posea et al., 2005). 


\section{Macrothink}

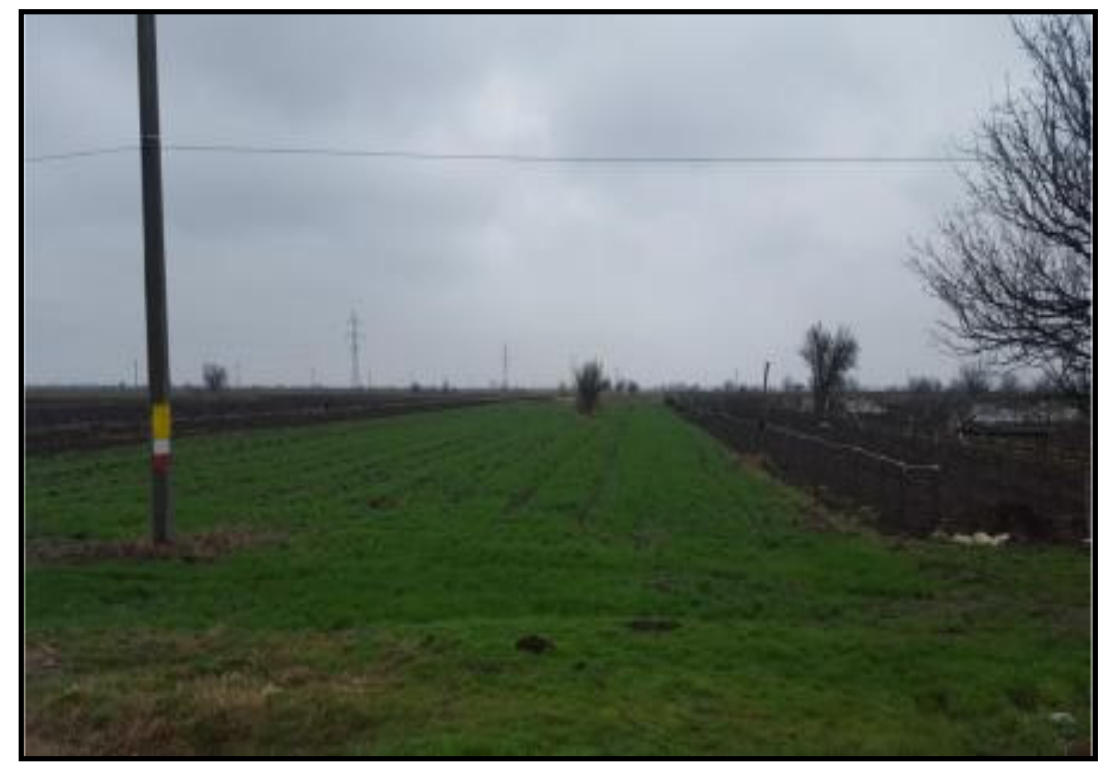

Figure 1. Lower terrace Danube the Giuvarasti

On the territory commune Giuvarasti floodability processes it occurs only in Olt floodplain and Valley Ursii. In periods of rainfall occur bank erosion and deepening of the riverbed valley (Figure 2).

From geological point of view, locality Giuvarasti belongs Moesian Platform, where today there quaternary deposits, starting with pleistocene. In depth were intercepted drilling and identified in outcrops present in adjacent areas oldest deposits of content Moesian Platform.

Quaternary form the cover surface (covering levantine) in which the studied area meet two specific lithological complex main forms of relief, namely complex loess-like characteristic Romanati Plain and complex alluvial characteristic for Olt floodplain.

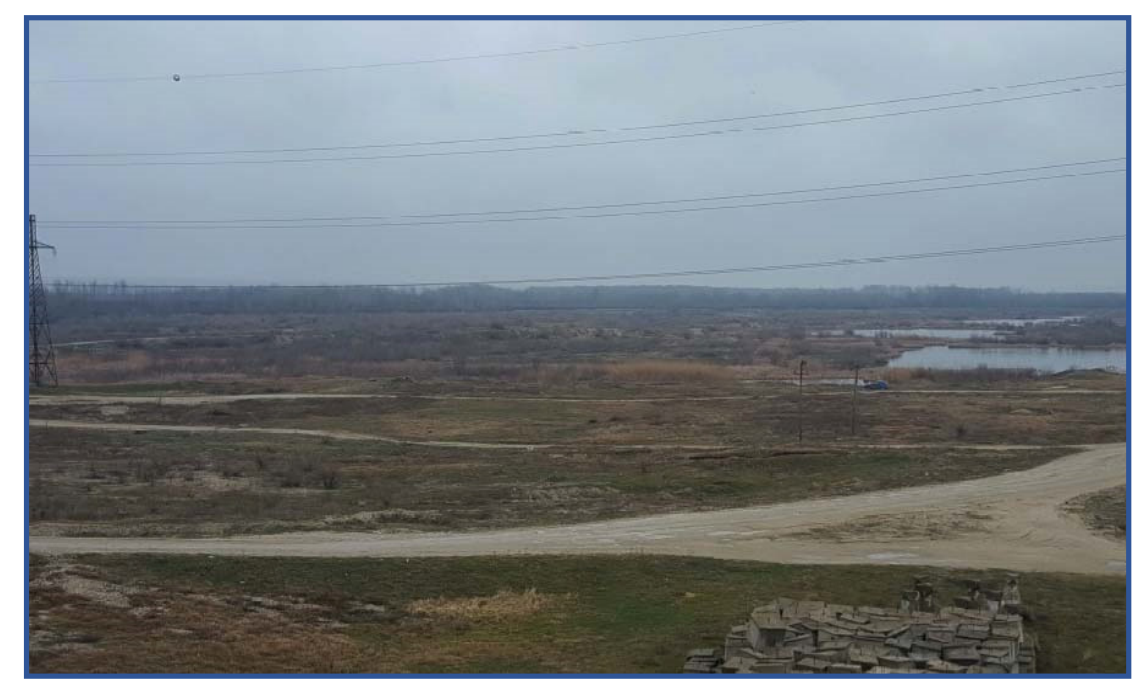

Figure 2. Olt floodplain the Giuvarasti 


\section{Macrothink}

The studied part Olt River basin the only river crossing the region under study at its eastern part and part of the irrigation system Sadova-Corabia it is crossed by a network of channels of supply and water discharge (Figure 3).

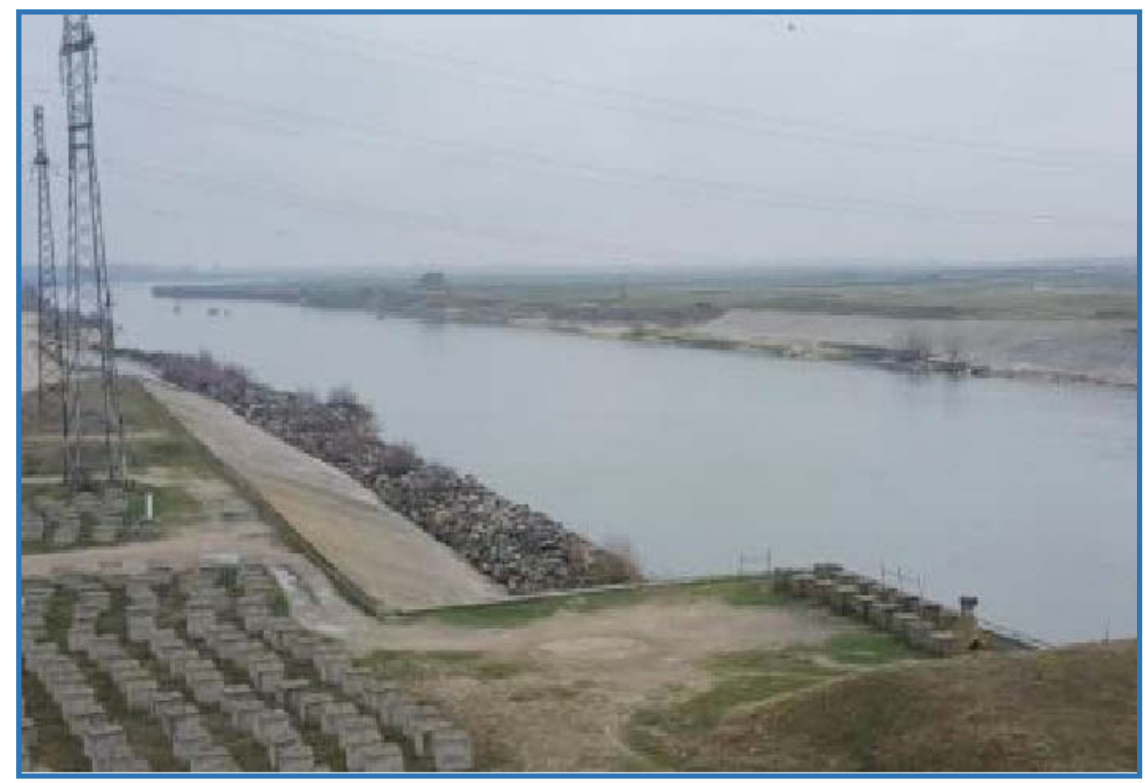

Figure 3. River Olt entry in locality Giuvarasti

The climate is temperate continental characterized by wide temperature variations between the summer and winter air masses caused by domination of eastern Europe, masses that bring frosts in winter and scorching heat of summer.

The annual average temperature is $11.5^{\circ} \mathrm{C}$ at station Turnu Magurele, with the average January $-2{ }^{\circ} \mathrm{C}$ and the July $22.8^{\circ} \mathrm{C}$. The annual quantity of precipitation is $500-600 \mathrm{~mm}$, the lowest amount in early autumn and the most abundant in June.

Due to high uniformity training conditions, soil cover of the locality Giuvarasti it has a very low diversification, is represented by soils with good natural fertility (chernozems), plus soils with low fertility and namely aluviosols (Ispas \& Stănilă, 2015).

Depending on the conditions and factors that have contributed to soil cover, in the researched they were identified following soils level class: protisols and cernisols (Figure 4).

Protisols class includes soils the younger, at an early stage of development, formed by repeated deposition of sediment it is represented by calcaric gleyic aluviosols (US1: ASka-gc-SM/SM).

Calcaric gleyic aluviosols (US1: ASka-gc-SM/SM) meet in Olt floodplain and Valley Ursii, on alluvial deposit/carbonate rocks eubazic, the groundwater situated between 2-3 m. Presents a profile of type Ao-CGox-Gr-Ck. The texture is sandy loam, soil reaction is slightly alkaline the depth of $0-100 \mathrm{~cm}$ (values between 8.0 to 8.4 ). Humus content is low $(1.7-2.0 \%$ ), the supply of phosphorus is low (16 ppm) and the mobile potassium high (260 ppm).

The area studied has a low fertility (54 points of evaluation for land in crop). 


\section{Macrothink}

Cernisols class are represented by typical chernozems (US2: CZti-LL/LL), proxicalcaric chernozems (US3: CZka1-LL/LN) and epicalcaric chernozems (US4: CZka2-LL/LL).

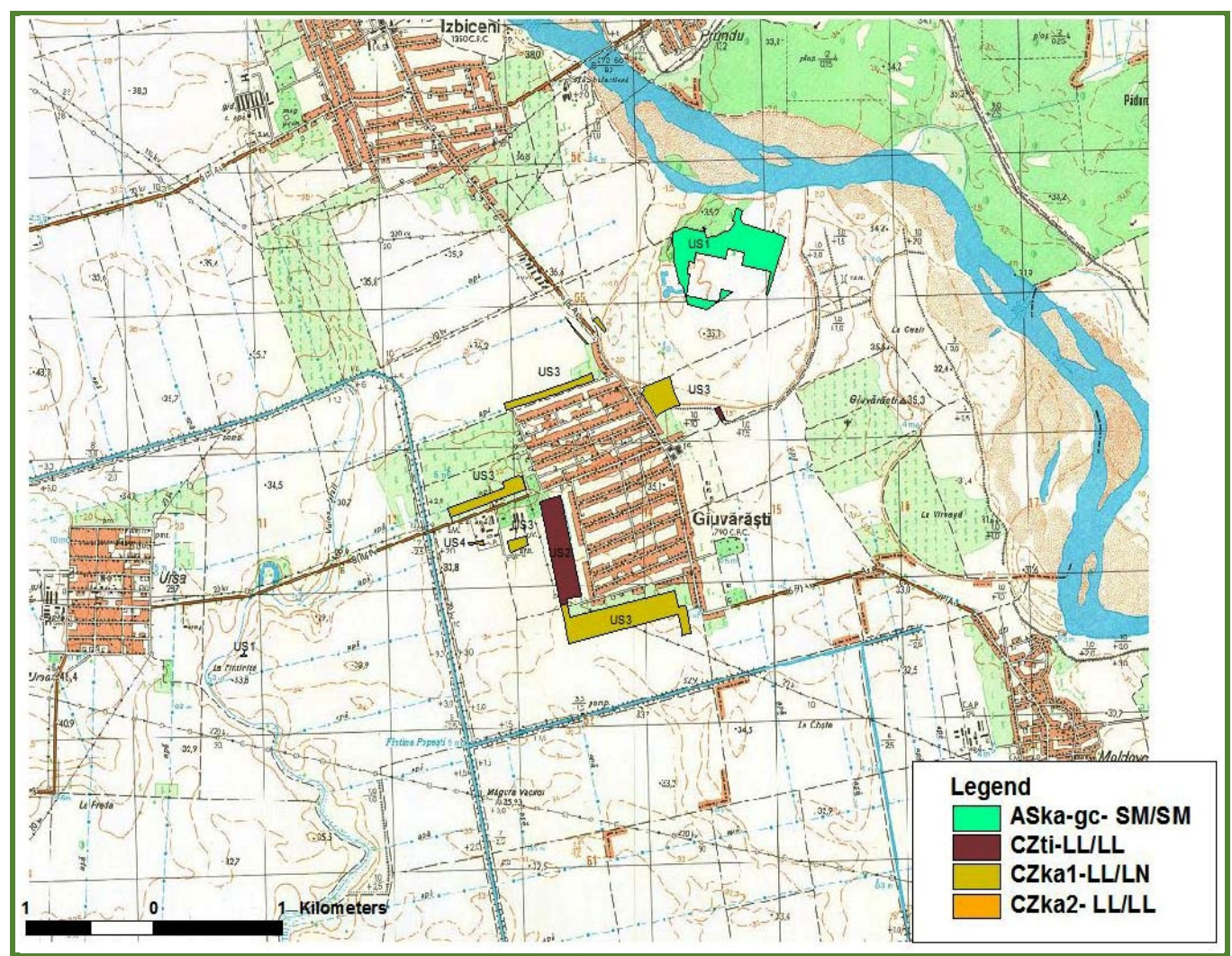

Figure 4. Soil map for the surface proposed to be introduced in buildable urban

(After Sorina Dumitru)

Typical chernozems (US2:CZti-LL/LL). These soils were formed under a plain relief, represented terrace Corabia the parent material made of loess-like deposit medium-fine, with groundwater depth of 3-5 m. Presents a profile of type Am-AC-C or Cca well developed.

Typical chernozems presents medium texture, loamy and soil reaction it is neutral $(\mathrm{pH}=6.9)$. Aeration porosity and permeability show low values, the humus content is high $(3.0-5.0 \%)$, and supplying phosphorus and potassium is very high cell (Mobile P - $72 \mathrm{ppm}$, Mobile K $301 \mathrm{ppm})$.

Proxicalcaric chernozems (US3:CZkal-LL/LN) were formed under a plain relief, represented terrace Corabia the parent material made of loess-like deposit/carbonate rocks eubazic, ground water depth of $5-10 \mathrm{~m}$. Presents a profile of type $A m-A C-C$ or $C c a$ well developed.

Texture is loamy, and soil reaction weak alkaline $(\mathrm{pH}=7.3$ to 8.1$)$. Aeration porosity and permeability show low values. Humus content is low $(2.5 \%)$ and supply soil nitrogen it is middle.

The supply soil phosphorus is low (Mobile $\mathrm{P}-18 \mathrm{ppm}$ ) and mobile potassium it is very high (Mobile K - 310 ppm).

Epicalcaric chernozems (US4:CZka $-L L / L L)$ were formed under a plain relief, represented 
terrace Corabia the parent material made of loess-like deposit/carbonate rocks eubazic, ground water depth of 5 - $7 \mathrm{~m}$. Presents a profile of type $A m-A C-C$ or $C c a$ well developed.

Texture is loamy, and soil reaction weak alkaline $(\mathrm{pH}=7.6)$. Aeration porosity and permeability show medium values. Humus content is low (2.7\%) and supply soil nitrogen it is middle. The supply soil phosphorus is low (Mobile P - $14 \mathrm{ppm}$ ) and mobile potassium it is high (Mobile K - 220 ppm).

Soil units identified in the area were characterized by their area ecopedological indicators, expressing properties of soil, terrain and climate (Table 1).

Table 1. Soil Units for the surface proposed to be introduced in buildable urban

\begin{tabular}{|c|c|c|c|c|c|}
\hline \multirow{2}{*}{ US } & \multirow{2}{*}{ Symbol } & \multirow{2}{*}{ Soil type } & \multirow{2}{*}{ Texture } & \multicolumn{2}{|c|}{ Surface } \\
\hline & & & & ha & $\%$ \\
\hline 1 & ASka-gc-SM/SM & $\begin{array}{l}\text { Calcaric } \\
\text { aluviosols }\end{array}$ & $\begin{array}{l}\text { Medium sandy loam/Medium } \\
\text { sandy loam }\end{array}$ & 23.02 & 33.67 \\
\hline 2 & CZti-LL/LL & Typical chernozems & Medium loam/Medium loam & 15.57 & 22.77 \\
\hline 3 & CZka1-LL/LN & $\begin{array}{l}\text { Proxicalcaric } \\
\text { chernozems }\end{array}$ & Medium loam/Sandy loamy clay & 29.55 & 43.23 \\
\hline 4 & CZka2- LL/LL & $\begin{array}{l}\text { Epicalcaric } \\
\text { chernozems }\end{array}$ & Medium loam/Medium loam & 0.23 & 0.33 \\
\hline & Total & & & 68.37 & $100 \%$ \\
\hline
\end{tabular}

On the basis of ecopedological indicators, they were assigned to the corresponding coefficients of evaluation with which were calculated note of evaluation, under natural conditions (current) for use categories (Table 2).

Table 2. Distribution on categories of use and class quality soil in the area of interest

\begin{tabular}{lllllllllllllll}
\hline Soil type & US Surface & Land in crop & \multicolumn{2}{l}{ Pasture } & \multicolumn{3}{l}{ Hay-field } & Orchards & Vine \\
\hline & & ha & NB* & Class & NB & Class & NB & Class & NB & Class & NB & Class \\
Calcaric gleyic aluviosols & 1 & 23.02 & 54 & III & 57 & III & 43 & III & 53 & III & 55 & III \\
Typical chernozems & 2 & 15.57 & 80 & II & 70 & II & 54 & III & 76 & II & 80 & II \\
Proxicalcaric chernozems & 3 & 29.55 & 58 & III & 56 & III & 43 & III & 62 & II & 72 & II \\
Epicalcaric chernozems & 4 & 0.23 & 49 & III & 56 & III & 43 & III & 46 & III & 54 & III \\
\hline
\end{tabular}

* Note of evaluation

In the Table 3 presents the surface proposed to be introduced in buildable urban for current use (land in crop, vine) on class quality. 


\section{Macrothink}

Table 3. The surface proposed to be introduced in buildable urban for current use category

\begin{tabular}{llll}
\hline Nr. & Category of use & Class quality & $\begin{array}{l}\text { Surface proposed to be introduced } \\
\text { in buidable urban (ha) }\end{array}$ \\
\hline 1 & Land in crop & II & 14.61 \\
& & III & 25.86 \\
& Total & & 40.47 \\
2 & Vine & III & 0.05 \\
& Total utilisation agricole & $\mathbf{4 0 . 5 2}$ \\
3 & Court-Building & NA* & 22.97 \\
4 & Roads & NA & 1.26 \\
5 & Waste land & NA & 3.62 \\
& \multicolumn{2}{l}{ Total nonagricultural } & $\mathbf{2 7 . 8 5}$ \\
& \multicolumn{2}{l}{ Total general } & $\mathbf{6 8 . 3 7}$ \\
\hline
\end{tabular}

* NA - Not applicable. Lands destination other than the utilization agricole does not require pedological evaluation.

\section{Conclusions}

Purpose pedological study was characterization of the soil cover the locality Giuvarasti, Olt County, in order to update the General Urban Plan. Surface proposed to be introduced in buildable urban represents 68.37 ha, of which 27.85 ha is land with another destination than farm utilization agricole, filled with court-building, roads and waste land does not require pedological evaluation.

Following the evaluation areas of interest were identified land classes quality II and III for current use land in crop, class quality III for current use vine and surface with nonagricultural land.

The pedological limitations of the soil cover the locality Giuvarasti, Olt County are caused by climatic conditions, groundwater depth, gleization, texture in the surface horizon, $\mathrm{CaCO}_{3}$ content, danger floodability, reserve of humus.

Due to the nature of the limiting factors and their degree of intensity, it can be considered that, in the General Urban Plan, these surfaces may be introduced in buildable urban.

\section{Acknowledgement}

The author thanks Journal of Applied Biotechnology, Macrothink Institute for financial support.

\section{References}

Coteţ, P. (1976). Romanian Plain. Integrated geomorphology study, Publisher Ceres, Bucharest. 


\section{Macrothink}

Florea, N., Munteanu, I., Rusu, C., Dumitru, M., Ianoş, Gh., Răducu, Daniela, Rogobete, Gh. \& Țărău, D. (2012). Romanian System of Soil Taxonomy. Sitech Publishing House, Bucharest, 206.

Ispas, Şt., Stănilă, Anca-Luiza (2015). Soils Romania. Publisher Valahia University Press, Targoviste, 246.

Parichi, M., Stănilă, Anca-Luiza, \& Cruceru, N. (2006). Soils main relief units in Romania Romania for Tomorrow Publishing House, Bucharest, 179.

Posea, Gr., Cruceru, N. (2005). Geomorphology Romania. Romania for Tomorrow Publishing House, Bucharest, 364.

Stănilă, Anca-Luiza \& Parichi, M. (2005). Glossary of soil science. Romania for Tomorrow Publishing House, Bucharest, 108.

Stănilă, Anca-Luiza, Parichi, M., \& Ursaru, P. (2010). Pedogeographical observations in the Plain between the Jiu and the Danube. Proceedings, USAMV Bucharest, Series A, Volume LIII.

Teaci, D. (1980). Economic value of agricultural land. Ceres Publishing House, Bucharest, 296.

\section{Copyright Disclaimer}

Copyright reserved by the author(s).

This article is an open-access article distributed under the terms and conditions of the Creative Commons Attribution license (http://creativecommons.org/licenses/by/3.0/). 